\title{
Blood-Tissue Barriers in the Male Reproductive Tract of the Dog: A Morphological Study Using Lanthanum Nitrate as an Electron-Opaque Tracer
}

\author{
Mireille Cambrosio Mann Armin E. Friess Michael H. Stoffel \\ Department of Veterinary Anatomy, University of Berne Veterinary School, Bern, Switzerland
}

\section{Key Words}

Blood-testis barrier - Blood-epididymis barrier . Intercellular space $\cdot$ Smooth muscle cells · Dog

\begin{abstract}
Blood-tissue barriers preventing an uncontrolled exchange of larger molecules between adjacent but metabolically separate compartments have been demonstrated in various organs. One prominent example is the blood-testis barrier which has been investigated in a number of species. A key function of this barrier is to shield developing germ cells from the immune system in order to avoid autoimmune reactions. This requirement also applies to the male excurrent duct system. Yet, very few investigations have addressed the morphology of the blood-epididymal barrier. The goal of the present study, therefore, was to revisit the blood-testis barrier in the dog and to identify the structures constituting the blood-epididymal barrier in this species. Lanthanum nitrate was used as a tracer for electron microscopy. In the testis, lanthanum had free access to the intercellular space of the seminiferous epithelium up to the Sertoli cell junctions. Similarly, epithelial tight junctions were found to represent the permeability barrier in the epidid-
\end{abstract}

\section{KARGER}

Fax +41613061234

E-Mail karger@karger.ch

www.karger.com
(C) 2003 S. Karger AG, Basel

1422-6405/03/1744-0162\$19.50/0

Accessible online at:

www. karger.com/cto ymis. The present study highlights species differences with respect to the blood-testis barrier and extends the knowledge of the blood-epididymal barrier by providing morphofunctional data in this domestic species.

Copyright $@ 2003$ S. Karger AG, Basel

\section{Introduction}

In specialized parts of the body, the free exchange of substances between blood and tissue cells is hindered by the presence of permeability gaskets. The function of such blood-tissue barriers which were first recognized in the late 19 th century is to prevent uncontrolled movement of larger molecules between adjacent but metabolically separate compartments. The barriers segregating the respective compartments have been identified in a number of different organs such as brain, retina, nerve tissue, thymus and testis. Depending on the organ studied, structures as different as the basal lamina, peritubular myoid cells, endothelial cells, or epithelial cells have been shown to be responsible for impeding free movement of molecules [Reese and Karnovsky, 1967; Dym and Fawcett, 1970; Fawcett et al., 1970; Raviola and Karnovsky, 1972].
PD Dr. Michael H. Stoffel

Postfach 8466

CH-3001 Bern (Switzerland)

Tel. +413163122 05, Fax +41316312615

E-Mail michael.stoffel@ita.unibe.ch 
The blood-testis barrier is a prominent example for a strict separation between basal and adluminal compartments within the seminiferous epithelium [Setchell et al., 1969]. It has been studied in a number of species such as man [Cavicchia et al., 1996], horse [Lopez et al., 1997], rat [Cavicchia et al., 1998], mink [Pelletier, 1994], and $\operatorname{dog}$ [Connell, 1978, 1980]. The blood-testis barrier plays a crucial role in normal spermatogenesis by shielding developing germ cells from blood-borne mutagenic substances and by preventing autoimmune reactions against sperm cells from occurring. As sperm cells remain in the male genital tract for weeks before being liberated, these requirements apply to the epididymis as well. Whereas epididymal spermatozoa are hardly susceptible to mutagenic damage because of their highly condensed chromatin, they still carry a wide range of potent antigens which can easily trigger an autoimmune response [Cropp and Schlaff, 1990; Meinertz et al., 1991; Bronson and Fusi, 1994]. Thus, contact between immune cells and spermatozoa must be avoided not only in the testis but all along the excurrent ducts as well. It is, therefore, surprising that although the impact of impaired epididymal integrity on autoimmune processes and infertility has been widely recognized [Cropp and Schlaff, 1990; Francavilla et al., 1992; Hinton and Palladino, 1995], very little attention has been paid to the presence and morphological equivalent of a blood-epididymis barrier so far.

The goal of the present work was to corroborate the presence of a blood-testis barrier in the dog and to provide morphofunctional evidence for the precise localization of the blood-epididymis barrier in this species. This was achieved by demonstrating the permeability barriers in transmission electron microscopy after tissue exposure to lanthanum nitrate as an electron-opaque tracer.

\section{Materials and Methods}

\section{Tissue Samples}

Testes with epididymides were obtained from 5 mature dogs (approximately $25 \mathrm{~kg}$ ) by castration.

\section{Fixation Procedure}

Perfusion Fixation. Within 5 min of removing the testis, a bulbheaded cannula was directly inserted into the testicular artery. The testis and epididymis were first thoroughly perfused with $0.9 \% \mathrm{NaCl}$. In one instance, rinsing was followed by a 20 - to 25 -min perfusion with fixative containing lanthanum (1\% lanthanum nitrate and $2 \%$ glutaraldehyde in $0.1 M$ cacodylate buffer, $\mathrm{pH}$ 7.2). Alternatively, lanthanum injection and fixation were performed sequentially. In this case, a perfusate containing [ $20 \mathrm{~m} M \mathrm{La}\left(\mathrm{NO}_{3}\right)_{3}, 80 \mathrm{~m} M \mathrm{NaCl}$, $3.5 \mathrm{~m} M \mathrm{KCl}, 1 \mathrm{~m} M \mathrm{CaCl}_{2}, 1 \mathrm{~m} M \mathrm{MgCl}_{2}, 1 \mathrm{~m} M$ glucose, $\mathrm{pH}$ 7.4] was perfused for 10 min [DePace, 1984; Xu et al., 1994]. The lanthanum nitrate solution was then followed by an additional 15 min perfusion with fixative ( $2 \%$ glutaraldehyde and $2 \%$ paraformaldehyde in a solution containing $43 \mathrm{mM} \mathrm{NaSO}, 16 \mathrm{~m} M \mathrm{NaHCO}_{3}, 10 \mathrm{~m} M$ sodium acetate, $3.5 \mathrm{~m} M \mathrm{KCl}, 1 \mathrm{~m} M \mathrm{CaCl}_{2}, 1 \mathrm{~m} M \mathrm{MgCl}_{2}, 1 \mathrm{~m} M$ glucose, $33 \mathrm{~m} M$ sucrose, $1.6 \mathrm{~m} M \mathrm{Na}_{2} \mathrm{HPO}_{4}, 0.4 \mathrm{~m} M \mathrm{NaH}_{2} \mathrm{PO}_{4}, \mathrm{pH}$ 7.4). Samples of about $1 \mathrm{~mm}^{3}$ were obtained from selected regions of the epididymis and testis. They were rinsed twice in a solution of $0.1 \mathrm{M}$ cacodylate containing $1 \%$ lanthanum nitrate and kept overnight at $4^{\circ} \mathrm{C}$ in the same solution.

Immersion Fixation. The testes and epididymides were rinsed under tap water and tissue blocks of about $1 \mathrm{~mm}^{3}$ were collected from corresponding epididymal regions and testis. Samples were then immersed in the above-mentioned fixative containing lanthanum $(1 \%$ lanthanum nitrate and $2 \%$ glutaraldehyde in $0.1 M$ cacodylate buffer, $\mathrm{pH}$ 7.2). They were kept overnight in $0.1 \mathrm{M}$ cacodylate containing $1 \%$ lanthanum nitrate.

Transmission Electron Microscopy. Samples were processed for transmission electron microscopy according to standard protocols. Briefly, samples were washed in cacodylate buffer and postfixed with $1 \% \mathrm{OsO}_{4}$ in $0.1 \mathrm{M}$ cacodylate buffer for $1 \mathrm{~h}$. After careful washing, the blocks were dehydrated in a graded series of ethanol and embedded in an Epon/Araldite mixture. Ultrathin sections were cut with a diamond knife on an Ultracut E microtome (Reichert-Jung, Vienna, Austria). To promote visualization of the tracer, ultrathin sections were left unstained. The sections were examined with a Zeiss EM 109.

\section{Results}

Within the epididymal epithelium, the distribution of lanthanum was similar after its application by perfusion and by immersion, respectively. However, tracer deposits were found within blood vessels, connective tissue and between peritubular muscle cells after perfusion fixation only.

\section{Blood-Testis Barrier}

In the testis, lanthanum had free access to the perivascular connective tissue. In perfused samples, the tracer was evenly distributed between peritubular contractile cells and accumulated underneath the basement membrane to a certain extent. Within the seminiferous epithelium, lanthanum was spread evenly between Sertoli cells and early stages of spermatogenesis (fig. 1) but was unable to pass the Sertoli cell junctions. It was gradually stopped by subsequent lines of membrane fusion (fig. 2).

\section{Blood-Epididymis Barrier}

The efferent ductules and five segments of the epididymal duct, i.e. proximal caput, distal caput, proximal corpus, distal corpus and proximal cauda, were investigated. No fundamental differences between these regions were 

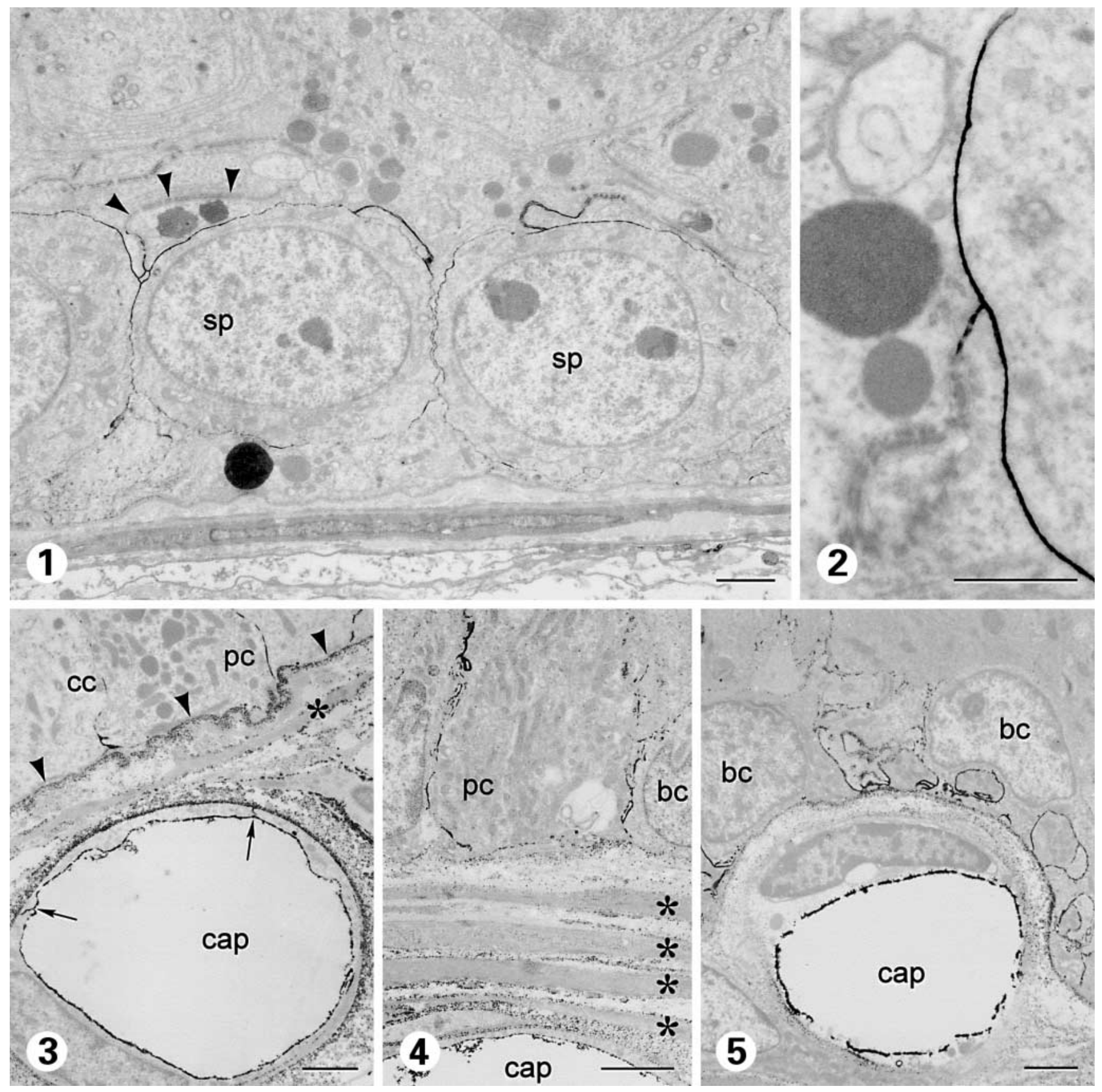

observed with respect to the extracellular distribution of lanthanum. Capillaries usually were located on the peripheral side of the smooth muscle layer in the proximal regions of the epididymis up to the proximal corpus (fig. 3, 4). From the distal corpus distad, however, capillaries often were situated immediately underneath the basement membrane and they often invaginated between the epithelial cells (fig. 5). Although capillaries observed were of the continuous type, endothelial cells did not impede extravasation of lanthanum. The tracer had access to the cleft between endothelial cells (fig. 3,4) and reached the perivascular tissue via the intercellular space without any perceptible hindrance. Finely granular and evenly distributed lanthanum deposits were found be- 

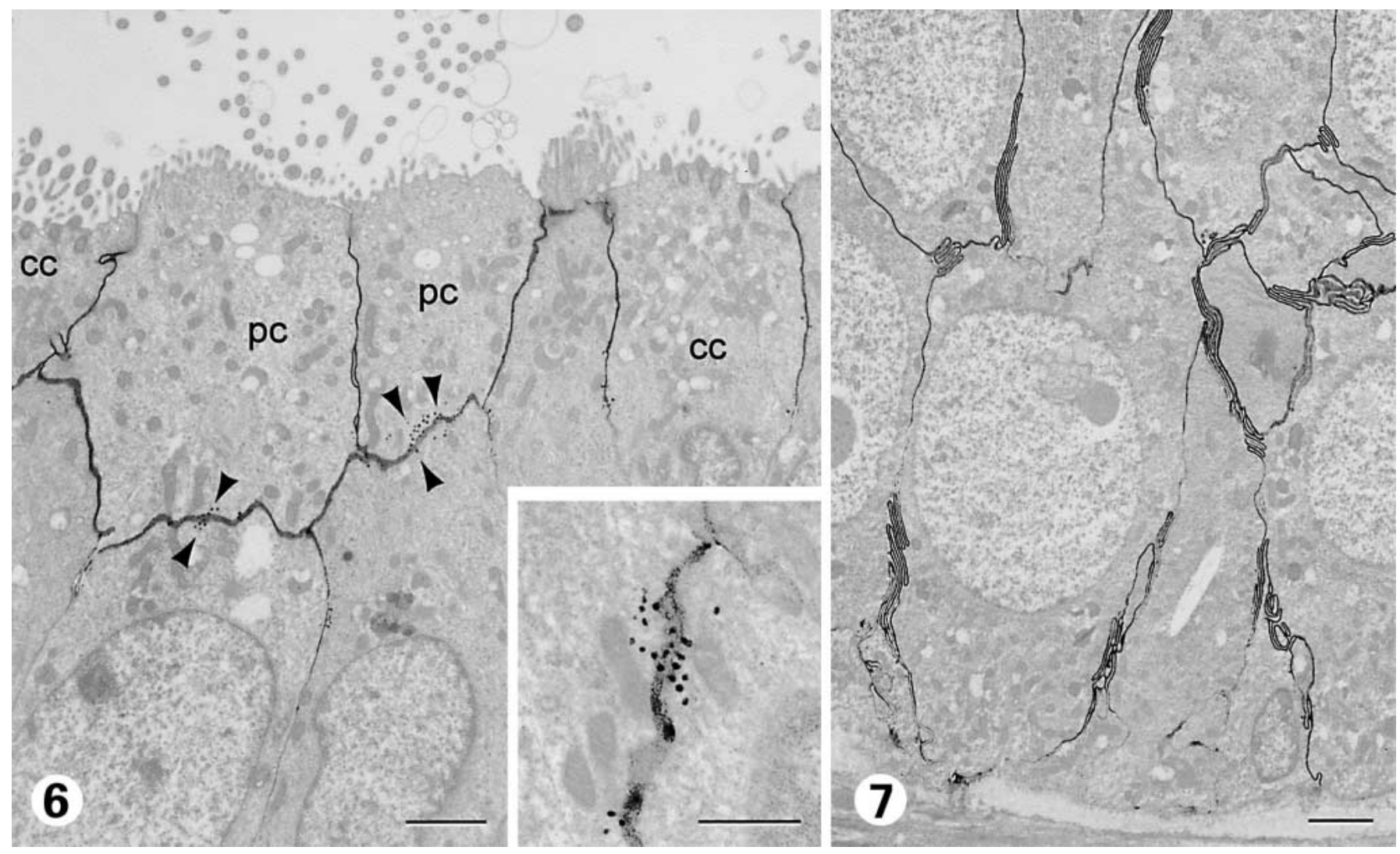

Fig. 1. Basal compartment of seminiferous epithelium. Tissue was exposed to lanthanum nitrate during immersion fixation. Tracer is evenly distributed between Sertoli cells and spermatocytes I (sp) up to the Sertoli cell junctions (arrowheads). Bar $=2 \mu \mathrm{m}$.

Fig. 2. Diffusion of lanthanum nitrate in the intercellular space is progressively stopped by successive lines of fusion of Sertoli cell junctions. Bar $=1 \mu \mathrm{m}$.

Fig. 3. Subepithelial capillary of efferent ducts (cap) after exposure to lanthanum nitrate by perfusion. Lanthanum is able to diffuse through the clefts between adjacent endothelial cells (arrows). The tracer is distributed in the perivascular tissue. It outlines smooth muscle cells (asterisk) and accumulates underneath the basement membrane (arrowheads). $\mathrm{cc}=$ Ciliated cell; $\mathrm{pc}=$ principal cell of efferent duct epithelium. Bar $=2 \mu \mathrm{m}$.

Fig. 4. Subepithelial capillary of proximal caput region (cap) after exposure to lanthanum nitrate by perfusion. Tracer evenly surrounds smooth muscle cells (asterisks) which are often present between capillaries and epididymal duct epithelium. $\mathrm{pc}=$ Principal cell; $\mathrm{bc}=\mathrm{bas}-$ al cell of epididymal duct epithelium. Bar $=2 \mu \mathrm{m}$.

tween smooth muscle cells (fig. 4) irrespective of the number of cell layers which increased from one in efferent ductules to an average of nine in proximal cauda. An accumulation of lanthanum underneath the epithelium made the basement membrane usually stand out (fig. 3, 5). Lanthanum nitrate had access to the intercellular space between epithelial cells up to the junctional complexes
Fig. 5. Subepithelial capillary of distal corpus region (cap) after exposure to lanthanum nitrate by perfusion. In the more distal regions of the epididymis, capillaries tend to invaginate between epithelial cells. Basal plasmalemma of epithelial cells forms pseudopode-like processes. $\mathrm{bc}=$ Basal cells. $\mathrm{Bar}=2 \mu \mathrm{m}$.

Fig. 6. Oblique section through apical region of efferent duct epithelium after exposure to lanthanum nitrate by immersion. The intercellular space is clearly revealed by the tracer up to the tight junctions. Intracellular vesicles containing lanthanum are found along the lateral plasma membrane of principal cells (arrowheads). $\mathrm{cc}=$ Ciliated cells; $\mathrm{pc}=$ principal cells. $\mathrm{Bar}=2 \mu \mathrm{m}$. Inset: Higher magnification of lanthanum-positive vesicles near lateral plasmalemma. Bar $=1 \mu \mathrm{m}$.

Fig. 7. Section through basal region of distal caput epithelium after exposure to lanthanum nitrate by immersion. Tracer in the intercellular space reveals the meandering of the lateral cell membranes at the infranuclear level. $\mathrm{Bar}=2 \mu \mathrm{m}$. 


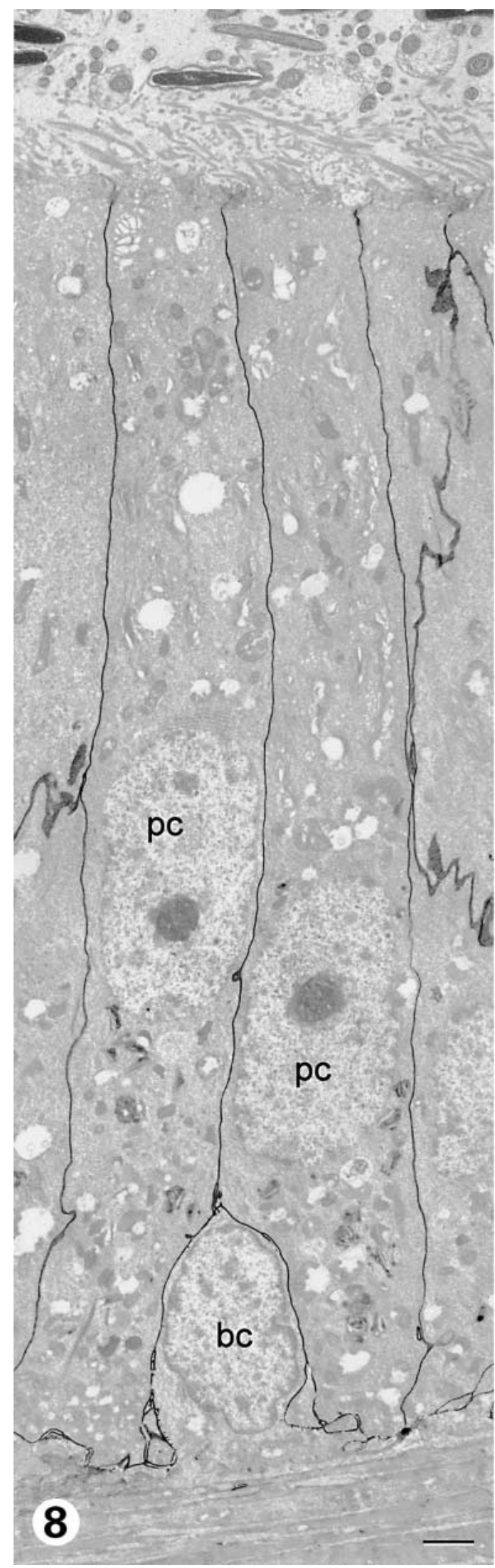

166

Cells Tissues Organs 2003;174:162-169

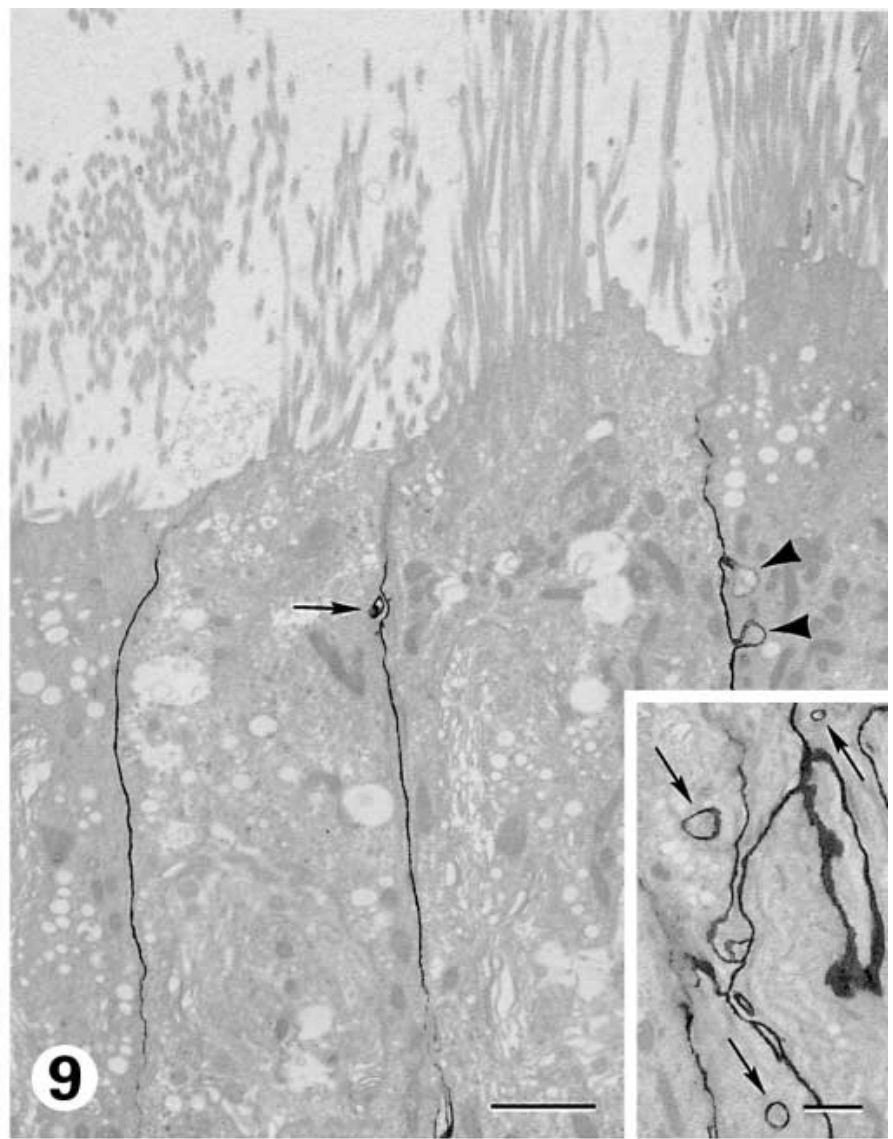

Fig. 8. Epididymal duct epithelium in the distal corpus region after exposure to lanthanum nitrate by immersion. The tracer outlines the intercellular space from the basement membrane up to the junctional complexes where it is stopped by the tight junctions. $b c=$ Basal cell; $\mathrm{pc}=$ principal cells. $\mathrm{Bar}=2 \mu \mathrm{m}$.

Fig. 9. Apical region of proximal cauda epithelium after exposure to lanthanum nitrate by immersion. Tracer in the intercellular space reveals finger-like projections (arrowheads) of the lateral plasma membrane. They appear as annular lanthanum deposits when cross-sectioned (arrow). Bar $=2 \mu \mathrm{m}$. Inset: Higher magnification of oblique section of lateral plasmalemma showing cross sections through finger-like projections (arrows). Bar $=1 \mu \mathrm{m}$. 
A specific feature of efferent duct principal cells was the presence of vesicles containing lanthanum (fig. 6 , inset). They were observed along the lateral cell membrane both near the basement membrane as well as below the junctional complexes.

Furthermore, the presence of lanthanum within the intercellular space clearly outlined the path of the lateral plasma membrane. A conspicuous meandering of the contact zone between adjacent cells produced a lamellar folding pattern at the infranuclear level of proximal and distal caput principal cells (fig. 7). Though less pronounced than in the caput region, lateral plasma membranes also displayed some degree of interdigitation in the proximal cauda. In addition, the intercellular plasma membrane displayed loose interdigitations in a subapical plane in the distal caput epithelium. Finger-like projections were typical of the subapical cellular interlocking in proximal cauda (fig. 9, inset) as revealed by annular lanthanum deposits. The basolateral cell membrane of principal and basal cells formed pseudopode-like processes in distal corpus and cauda regions (fig. 5). Moreover, elaborate interdigitations were typical for the contact zone between principal cells and apical cells. The latter cell type was encountered all along the caput and corpus epididymis.

\section{Discussion}

In the male reproductive tract, blood-tissue barriers fulfil a number of organotypic functions. They provide the highly specialized milieus required for spermatogenesis and sperm maturation [Sharpe, 1994; Hinton and Palladino, 1995; Meyer et al., 1996], they protect testicular germ cells and maturing spermatozoa from mutagenic or otherwise harmful substances [Schulze, 1992; Hinton et al., 1995, 1996], and, finally, they shield potent testicular and epididymal sperm antigens from the immune system. The breakdown of blood-tissue barriers in the testis and excurrent duct system results in the production of agglutinating or immobilizing antisperm antibodies [Hargreave et al., 1982; von Boehmer, 1988; Pöllänen and Cooper, 1994; Saari et al., 1996; Flickinger et al., 1998] which are known to significantly interfere with male fertility [Rumke et al., 1974; Hargreave et al., 1982; Herr et al., 1989; Handley et al., 1991; Francavilla et al., 1992; Flickinger et al., 1993; Hooper et al., 1995]. Thus, the blood-epididymis barrier is no less important than the blood-testis barrier and yet has received very little attention to date [Howards et al., 1976; Hoffer and Hinton, 1984; Agarwal and Hoffer, 1989].

Blood-Tissue Barriers in the Male Dog
Depending on the organ studied, the morphological equivalent of the respective blood-tissue barrier has been localized to quite different cells and structures [Reese and Karnovsky, 1967; Dym and Fawcett, 1970; Fawcett et al., 1970; Raviola and Karnovsky, 1972; Neaves, 1973; Janossy et al., 1980; Setchell et al., 1994; Xu et al., 1994; Rizzolo, 1997; Setchell, 1998]. Thus, the capillary endothelium, peritubular myoid cells, basement membrane, and epithelial tight junctions must be taken into consideration when identifying the structural components of a blood-tissue barrier. Permeability is best assessed functionally by using lanthanum nitrate as an electron-dense tracer given that not even the number of strands of tight junctions is a reliable indicator of junctional tightness [Hoffer et al., 1972; Martinez-Palomo and Erlij, 1975; Pelletier and Byers, 1992]. At first sight, immersion of tissue fragments in a fixative solution containing lanthanum may appear methodically questionable. In order to simulate the natural situation as best as possible, we also perfused the vascular system prior to fixation with a cell culture medium containing the tracer. Distribution of lanthanum within the epithelial intercellular space was identical after all protocols used. This is in agreement with previous authors, which also came to the conclusion that administration of lanthanum by either immersion or perfusion yields identical distribution patterns [Neaves, 1973]. However, limitation of free movement of molecules by the vascular wall and by subepithelial tissue elements only can be appreciated when lanthanum is administered by perfusion.

The blood-testis barrier has been investigated extensively in a number of species [Setchell et al., 1969; Dym and Fawcett, 1970; Howards et al., 1976; Connell, 1978, 1980; Turner et al., 1981; De Kretser and Kerr, 1994; Cavicchia et al., 1996; Setchell, 1998]. In all animals studied, Sertoli cell junctions ultimately prevent paracellular exchange of substances between basal and adluminal compartments. In laboratory rodents, however, peritubular myoid cells are believed to restrict the access of electron-dense markers to the seminiferous tubule as well [De Kretser and Kerr, 1994]. Our results show that contractile cells do not represent such an impediment in the dog, which is congruent with the situation in other domestic mammals [Fawcett, 1975, 1977]. The basement membrane, however, does delay the passage of tracer in the dog as is revealed by the accumulation of lanthanum underneath this structure.

In the canine epididymis, neither the vascular endothelium nor subepithelial tissue elements did hold back intravascularly perfused lanthanum. Thus, the epithelial

Cells Tissues Organs 2003; 174:162-169 
tight junctions are the ultimate structural component of the blood-epididymis barrier as has also been shown for the rat [Hoffer and Hinton, 1984; Agarwal and Hoffer, 1989]. This is consistent with the facts that epididymal capillaries are even more permeable than testicular capillaries [Kormano, 1967; Hamilton, 1972], and that the epididymis harbors the best-developed tight junctions anywhere except seminiferous tubules [Friend and Gilula, 1972; Agarwal and Hoffer, 1989].

The presence of lanthanum in intracellular vesicles near the lateral cell membrane was typical of the efferent ducts. Extensive endocytic activity of efferent duct principal cells requires highly effective mechanisms to ensure appropriate recycling of cell membranes. As tracer was only available at the basolateral cell surface, vesicles containing lanthanum most likely reflect a turnover of the cell membrane. Morphological evidence for a turnover of lateral plasma membranes including junctions has also been reported in the rat [Cyr et al., 1995]. The annular lanthanum deposits observed near the plasmalemma in proxi- mal cauda epithelium are interpreted as being cross sections through interdigitations of the lateral plasma membrane.

In the present study, we successfully demonstrated the blood-tissue barriers in the male reproductive tract of the dog by using lanthanum nitrate as an electron-dense tracer. In contrast to the situation in laboratory rodents, the blood-testis barrier was exclusively localized to the Sertoli cell junctions. In the excurrent duct system, lanthanum gained access to the intercellular space up to the junctional complexes. Thus, the tight junctions in efferent ductule and epididymal duct epithelia are the morphological equivalent of the blood-epididymis barrier.

\section{Acknowledgments}

The technical support of C. Furer and C. Hug is gratefully acknowledged. We are also indebted to S. König for photographic work.

\section{References}

Agarwal, A., A.P. Hoffer (1989) Ultrastructural studies on the development of the blood-epididymis barrier in immature rats. $\mathrm{J}$ Androl 10 : 425-431.

Bronson, R.A., F.M. Fusi (1994) Autoimmunity to sperm antigens. Immunol Allergy Clin North Am 14: 773-786.

Cavicchia, J.C., F.L. Sacerdote, L. Ortiz (1996) The human blood-testis barrier in impaired spermatogenesis. Ultrastruct Pathol 20: 211-218.

Cavicchia, J.C., F.L. Sacerdote, A. Morales, B.C. Zhu (1998) Sertoli cell nuclear pore number changes in some stages of the spermatogenic cycle of the rat seminiferous epithelium. Tissue Cell 30: 268-273.

Connell, C.J. (1978) A freeze-fracture and lanthanum tracer study of the complex junction between Sertoli cells of the canine testis. J Cell Biol 76: 57-75.

Connell, C.J. (1980) Blood-testis barrier formation and the initiation of meiosis in the dog; in Steinberger, A., E. Steinberger (eds): Testicular Development, Structure, and Function. New York, Raven Press, pp 71-78.

Cropp, C.S., W.D. Schlaff (1990) Antisperm antibodies. Arch Immunol Ther Exp 38: 31-46.

Cyr, D.G., B. Robaire, L. Hermo (1995) Structure and turnover of junctional complexes between principal cells of the rat epididymis. Microsc Res Tech 30: 54-66.

De Kretser, D.M., J.B. Kerr (1994) The cytology of the testis; in Knobil, E., J. Neill, L.L. Ewing, G.S. Greenwald, C.L. Markert, D.W. Pfaff (eds): The Physiology of Reproduction. New York, Raven Press, pp 1177-1290.
DePace, D.M. (1984) Distribution of intravascularly injected lanthanum ions in ganglia of the autonomic nervous system of the rat. J Auton Nerv Syst 11: 339-347.

Dym, M., D.W. Fawcett (1970) The blood-testis barrier in the rat and the physiological compartmentation of the seminiferous epithelium. Biol Reprod 3: 308-326.

Fawcett, D.W. (1975) Ultrastructure and function of the Sertoli cell; in Hamilton, D.W., R.O. Greep (eds): Handbook of Physiology. Washington, American Physiological Society, pp 2155 .

Fawcett, D.W. (1977) The ultrastructure and functions of the Sertoli cell; in Green, R.O., M.A. Koblinsky (eds): Frontiers in Reproduction and Fertility. Cambridge, MIT Press, pp 302320 .

Fawcett, D.W., L.V. Leak, P.M.J. Heidger (1970) Electron microscopic observations on the structural components of the blood-testis barrier. J Reprod Fertil Suppl 10: 105-122.

Flickinger, C.J., M.L. Baran, S.S. Howards, J.C. Herr (1998) Epididymal obstruction during development results in antisperm autoantibodies at puberty in rats. J Androl 19: 136-144.

Flickinger, C.J., J.C. Herr, J.R. Sisak, S.S. Howards (1993) Ultrastructure of epididymal interstitial reactions following vasectomy and vasovasostomy. Anat Rec 235: 61-73.

Francavilla, F., R. Romano, R. Santucci, V. Marrone, G. Corrao (1992) Failure of intrauterine insemination in male immunological infertility in cases in which all spermatozoa are antibodycoated. Fertil Steril 58: 587-592.
Friend, D.S., N.B. Gilula (1972) Variations in tight and gap junctions in mammalian tissues. $\mathrm{J}$ Cell Biol 53: 758-776.

Hamilton, D.W. (1972) The mammalian epididymis; in Balin, H., S. Glasser (eds): Reproductive Biology. Amsterdam, Excerpta Medica, pp 268-337.

Handley, H.H., J.C. Herr, C.J. Flickinger (1991) Localization of post-vasectomy sperm autoantigens in the Lewis rat. J Reprod Immunol 20: 205-220.

Hargreave, T.B., A. Busuttil, R.A. Elton, J. Harvey, A. Chan, G.D. Chisholm (1982) Studies of testicular and epididymal damage in relation to the occurrence of antisperm antibodies. $\mathrm{Br} \mathrm{J}$ Urol 54: 769-773.

Herr, J.C., S.S. Howards, D.R. Spell, P.O. Carey, S.J. Kendrick, T.N. Gallien, H.H. Handley, C.J. Flickinger (1989) The influence of vasovasostomy on antisperm antibodies in rats. Biol Reprod 40: 353-360.

Hinton, B.T., M.A. Palladino (1995) Epididymal epithelium: Its contribution to the formation of a luminal fluid microenvironment. Microsc Res Tech 30: 67-81.

Hinton, B.T., M.A. Palladino, D. Rudolph, J.C. Labus (1995) The epididymis as protector of maturing spermatozoa. Reprod Fertil Dev 7 : 731-745.

Hinton, B.T., M.A. Palladino, D. Rudolph, Z.J. Lan, J.C. Labus (1996) The role of the epididymis in the protection of spermatozoa; in Pedersen, R.A., G.P. Schatten (eds): Current Topics in Developmental Biology. San Diego, Academic Press, vol 33, pp 61-102. 
Hoffer, A.P., D.W. Hamilton, D.W. Fawcett (1972) The ultrastructural pathology of the rat epididymis after administration of alpha-chlorhydrin (U-5897). Anat Rec 175: 203-230.

Hoffer, A.P., B.T. Hinton (1984) Morphological evidence for a blood-epididymis barrier and the effects of gossypol on its integrity. Biol Reprod 30: 991-1004.

Hooper, P., E. Smythe, R.C. Richards, C.V. Howard, R.V. Lynch, D.I. Lewis-Jones (1995) Total number of immunocompetent cells in the normal rat epididymis and after vasectomy. $\mathrm{J}$ Reprod Fertil 104: 193-198.

Howards, S.S., S.J. Jessee, A.L. Johnson (1976) Micropuncture studies of the blood-seminiferous tubule barrier. Biol Reprod 14: 264-269.

Janossy, G., J.A. Thomas, F.J. Bollum, S. Granger, G. Pizzolo, K.F. Bradstock, L. Wong, A. McMichael, K. Ganeshaguru, A.V. Hoffbrand (1980) The human thymic microenvironment: An immunohistologic study. J Immunol 125 . 202-212.

Kormano, M. (1967) Dye permeability and alkaline phosphatase activity of testicular capillaries in the postnatal rat. Histochemie 9: $327-$ 338.

Lopez, M.L., P. Fuentes, C. Retamal, W. Desouza (1997) Regional differentiation of the bloodepididymis barrier in stallion (Equus caballus). J Submicrosc Cytol Pathol 29: 353-363.

Martinez-Palomo, A., D. Erlij (1975) Structure of tight junctions in epithelia with different permeability. Proc Natl Acad Sci USA 72: 44874491.

Meinertz, H., L. Linnet, H. Wolf, T. Hjort (1991) Antisperm antibodies on epididymal spermatozoa. Am J Reprod Immunol 25: 158-162.
Meyer, J.M., P. Mezrahid, E. Vignon, G. Chabrier, D. Reiss, Y. Rumpler (1996) Sertoli cell barrier dysfunction and spermatogenetic cycle breakdown in the human testis: A lanthanum tracer investigation. Int J Androl 19: 190-198.

Neaves, W.B. (1973) Permeability of Sertoli cell tight junctions to lanthanum after ligation of ductus deferens and ductuli efferentes. J Cell Biol 59: 559-572.

Pelletier, R.M. (1994) Blood barriers of the epididymis and vas deferens act asynchronously with the blood barrier of the testis in the mink (Mustela vison). Microsc Res Tech 27: 333-349.

Pelletier, R.M., S.W. Byers (1992) The blood-testis barrier and Sertoli cell junctions: Structural considerations. Microsc Res Tech 20: 3-33.

Pöllänen, P., T.G. Cooper (1994) Immunology of the testicular excurrent ducts. J Reprod Immunol 26: 167-216.

Raviola, E., M.J. Karnovsky (1972) Evidence for a blood-thymus barrier using electron-opaque tracers. J Exp Med 136:466-498.

Reese, T.S., M.J. Karnovsky (1967) Fine structural localization of a blood-brain barrier to exogenous peroxidase. J Cell Biol 34: 207-217.

Rizzolo, L.J. (1997) Polarity and the development of the outer blood-retinal barrier. Histol Histopathol 12: 1057-1067.

Rumke, P., N. Van Amstel, E.N. Messer, P.D. Bezemer (1974) Prognosis of fertility of men with sperm agglutinins in the serum. Fertil Steril 25: 393-398.

Saari, T., K. Jahnukainen, P. Pöllänen (1996) Autoantigenicity of the basal compartment of seminiferous tubules in the rat. J Reprod Immunol 31: 65-79.
Schulze, C. (1992) Interaktionen zwischen Leydigzellen - peritubulären Zellen - Sertolizellen und ihre Bedeutung für die Steuerung der Spermatogenese. Ann Anat 174: 509-515.

Setchell, B.P. (1998) Blood-testis barrier; in Knobil, E., J.D. Neill (eds): Encyclopedia of Reproduction. San Diego, Academic Press, pp 375-381.

Setchell, B.P., S. Maddocks, D.E. Brooks (1994) Anatomy, vasculature, innervation, and fluids of the male reproductive tract; in Knobil, E., J. Neill, L.L. Ewing, G.S. Greenwald, C.L. Markert, D.W. Pfaff (eds): The Physiology of Reproduction. New York, Raven Press, pp 1063 1175.

Setchell, B.P., J.K. Voglmayr, G.M. Waites (1969) A blood-testis barrier restricting passage from blood into rete testis fluid but not into lymph. J Physiol 200: 73-85.

Sharpe, R.M. (1994) Regulation of spermatogenesis; in Knobil, E., J. Neill, L.L. Ewing, G.S. Greenwald, C.L. Markert, D.W. Pfaff (eds): The Physiology of Reproduction. New York, Raven Press, pp 1363-1434.

Turner, T.T., D.A. D'Addario, S.S. Howards (1981) The blood epididymal barrier to $\left[{ }^{3} \mathrm{H}\right]$ inulin in intact and vasectomized hamsters. Invest Urol 19: 89-91.

von Boehmer, H. (1988) The developmental biology of T lymphocytes. Annu Rev Immunol 6 : 309-326.

Xu, J., E.A. Ling (1994) Studies of the ultrastructure and permeability of the blood-brain barrier in the developing corpus callosum in postnatal rat brain using electron dense tracers. $\mathrm{J}$ Anat 184: 227-237. 